\title{
Host Status of Plantain Hybrids FHIA 21 and PITA 3 for Populations of Radopholus similis and Pratylenchus coffeae in Côte D'ivoire
}

\section{${ }^{* 1}$ Vawa Otro Serge Theodore, ${ }^{2}$ Adiko Amoncho, ${ }^{3}$ Gnonhouri Goly Philippe, ${ }^{4}$ Otchoumou Atcho}

\author{
${ }^{1,4} 02$ BP 801 Abidjan 02, Université Nangui Abrogoua, Côte d'Ivoire. \\ ${ }^{2,3} 01$ BP 1536 Abidjan 01, Centre National de Recherche Agronomique, Côte d'Ivoire, Station \\ de Bimbresso.
}

Article No.: 101416162

DOI: 10.15580/GJAS.2016.9.101416162

Submitted: 14/10/2016

Accepted: 21/10/2016

Published: $31 / 10 / 2016$

*Corresponding Author

Vawa Otro Serge Theodore

E-mail:vost_83@yahoo.fr

\section{Keywords:}

Radopholus similis, Pratylenchus coffeae, Plantain hybrids, PITA 3, FHIA 21, HORNE 1, resistance, susceptibility, threshold
Background: The work herein reported has been conducted in the framework of the implementation of the strategy of food security strategy in Côte d'Ivoire. In this perspective, FHIA 21 and PITA 3, two high yielding plantain hybrids, resistant to black Sigatoka have been assessed relatively to their response to Radopholus similis and Pratylenchus coffeae.

Methods: FHIA 21 and PITA 3 were inoculated with increasing inoculum levels of the parasites under monoxenic conditions: $5,10,15$ and $20 R$. similis or $P$. coffeae/g roots and dixenic conditions: $3 R$. similis and $3 P$. coffeae; $5 R$. similis and $5 P$. coffeae; $10 R$. similis and $10 P$. coffeae; $10 R$. similis and $5 P$. coffeae; 5 $R$. similis and $10 P$. coffeae/g roots. The cultivar HORNE 1 served as susceptible reference in both trials that were conducted in the glasshouse for eight weeks. Results: FHIA 21 appeared resistant to $R$. similis $(R=0.98)$ and susceptible to $P$. coffeae $(R=2.99)$. As to PITA 3, it was susceptible to both $R$. similis $(R=2.47)$ and $P$. coffeae $(R=2.94)$. Host suitability was further confirmed when comparing nematode reproduction under the hybrids to that under HORNE 1. FHIA 21 was designated slightly resistant to $R$. similis with a reproduction of $40.22 \%$ and susceptible to $P$. coffeae (83.27\%). The susceptibility of PITA 3 was also confirmed to $R$. similis (83.27\%) and $P$. coffeae $(73.63 \%)$.

Conclusion: With $R$. similis, the threshold of 10 nematodes $/ g$ of roots commonly used for rational nematicide applications in banana cultivation was confirmed. In the light of the predominance of $P$. coffeae in banana and plantain agrosystems in Côte d'Ivoire, the new reference threshold of $5 P$. coffeae/g roots is recommended for an effective management of plant-parasitic nematode pressure. 


\section{INTRODUCTION}

Plantains are an important staple food and a source of income for more than 400 million people in nearly 120 countries in tropical and intertropical zones (Jones, 2000). In Côte d'Ivoire, the production of plantains is estimated at 1.6 million tons, making it the third food crop in volume after yam and cassava (Anonymous, 2016). Despite its importance, plantain production does not cover domestic demands with an average per capita consumption of $120 \mathrm{~kg}$; the situation is further exacerbated by a sub-regional market of plantain steadily rising. The biotic and abiotic factors accounting for the low productivity of the crop have been well described (Lassoudière, 2009; Baker et al., 1997). Plant-parasitic nematodes represent one of the major biotic constraints on production (Bridge and al., 1995; Gowen and Quenehervé, 1990). Radopholus similis and Pratylenchus coffeae considered as the most destructive species (Sarah and al., 1996) can cause up to $60 \%$ yield loss. For very long, the nematofauna associated with banana and plantain cultivations in Côte d'Ivoire has been dominated by $R$. similis; $P$. coffeae was barely detectable (Adiko, 1989; Sarah, 1989). However, the pest situation has greatly evolved, as the orchards of banana and plantain harbor the two most damaging parasitic nematode species of the crops (Adiko and N'guessan, 2001; Sarah, 2000; Gnonhouri and Adiko, 2008; Gnonhouri and al., 2009). The cohabitation of the two species represents a real threat to the economy of banana agriculture, in general, and that of plantain, in particular. If chemical control which is generally recommended is a common practice in the commercial banana orchard, it is very rare in plantain cultivation that is dominated by small family farms. Moreover, land pressure and related problems do no longer allow the practice of extensive agriculture as an alternative measure for the management of parasites and other limiting factors (Gowen and Quénéhervé 1990). According to the work of De waele (1996) and Pinochet (1996), Musa genepool offers credible opportunities that could be exploited for resistance breeding for nematode management. In this perspective and in the context of improving the productivity of plantain in Côte d'Ivoire, the Centre National de Recherche Agronomique (CNRA, Côte d'Ivoire) has selected and is in the process of disseminating two tetraploid varieties of plantain FHIA 21 and PITA 3, for both their high yield, their resistance to black Sigatoka (Anonymous, 1987; Vuylsteke and al., 1993). The study reported herein aims at evaluating the hybrid host status for the populations of $R$. similis and $P$. coffeae in Côte d'Ivoire.

\section{MATERIALS AND METHODS}

Area of study. The study was carried in the greenhouse, at the Research Station of the Centre National de Recherche Agronomique (CNRA), at
Bimbresso, Côte d'Ivoire, West Africa. Bimbresso is located at $25 \mathrm{~km}$ in the West of Abidjan, at $5^{\circ} 19^{\prime} 14 \mathrm{~N}$, $4^{\circ} 40^{\prime} 20 \mathrm{~W}$ and $23 \mathrm{~m}$ above sea level. Average annual temperature was $26 \pm 1.34{ }^{\circ} \mathrm{C}$.

Planting materiel: Three cultivars were involved in the study. HORNE 1 is a triploid plantain, Musa spp. $A A B$ group and is the cultivar commonly grown in Côte d'Ivoire. HORNE 1 is considered susceptible to plantparasitic nematodes (Thiémélé, 2015. Personal communication). FHIA 21 and PITA 3 are plantain-like hybrids belonging to the genome group $A A A B$ with a ploidy level of $4 x$. These hybrids result from crosses between AAB Plantain CV. AVP-67 x SH-3142 and $A A B$ Plantain cv. Obino l'Ewaï $x$ Calcutta 4, respectively. In-vivo micropropagated plantain plantlets of the three genotypes were used (Thiémélé and al., 2015). Forty five days old in-vivo plantlets at the end of the weaning period were transplanted in 6-liter buckets filled with sterile mixture of 5 parts of soil, 1 part of sand and 2 parts of peat.

Preparation of Nematodes inoculum: $R$. similis and $P$. coffeae were collected from roots of naturally infested plantain trees established at the experimentation site of the CNRA at Azaguié. Nematodes were extracted according to Seinhorst method (1950) and each species reared on sterilized carrot discs as described by (Boisseau and Sarah, 2008). After incubation at $28^{\circ} \mathrm{C}$ in darkness during 8 weeks, nematodes were extracted from carrot discs as follows. Carrot discs containing the reared nematodes were macerated in a blender for 10 seconds (two periods of 10 seconds separated by a 5 second interval). The resulting mixture was passed through two sieves of 106 and $25 \mu \mathrm{m}$ respectively. Carrot tissue and debris collected on the $106 \mu \mathrm{m}$ sieve were discarded, and nematodes on the $25 \mu \mathrm{m}$ sieve were recovered in test tubes (Boisseau and Sarah, 2008). Three $1 \mathrm{ml}$ samples of the resulting suspensions were pipetted in graduated counting dishes and number of each nematode species determined under a dissecting microscope. The total population density of each species was estimated by converting the mean value of samples into total volume.

\section{Inoculation of plantain plantlets}

In 1972, Guerout has determined a level of $10 R$. similis per $g$ of roots as the threshold for the management of nematodes in banana orchard. On that basis, the following treatments were applied on each plantain variety in the study herein reported.

\section{In monoxenic inoculation}

i) Check (without nematodes);

ii) 5 nematodes/g roots;

iii) 10 nematodes/g roots;

iv) 15 nematodes/g roots; 
v) 20 nematodes/g roots.

\section{In dixenic inoculation}

i) Check (without nematodes);

ii) 6 nematodes $/ g$ roots $(3 R$. similis and $3 P$. coffeae);

iii) 10 nematodes $/ g$ roots $(5 R$. similis and $5 P$. coffeae);

iv) 15 nematodes / g roots $(10 R$. similis and $5 P$. coffeae);

v) 15 nematodes $/ g$ roots $(5 R$. similis and $10 P$. coffeae);

vi) 20 nematodes $/ g$ roots $(10 R$. similis and $10 P$. coffeae).

In order to calibrate the nematode suspension to be pipetted for inoculation according to the initial densities set above, 10 plantlets of each genotype were uprooted. Roots were delicately washed with tap water and the average fresh weight determined. Plantlets were inoculated one week after transplanting. For the inoculation per set, nematodes were collected from the calibrated suspension and applied with a micropipette in three holes $(5 \mathrm{~cm}$ deep and $0.5 \mathrm{~cm}$ diameter) made in the soil around the pseudostem. Holes were reclosed with the same soil substrate and plantlets lightly watered. Each treatment was replicated six times. Treatment replicates were arranged in a completely randomized design in the greenhouse where temperature ranged from $27-28^{\circ} \mathrm{C}$ and humidity from $80-90 \%$.

Extraction and assessment of final nematode populations: Eight weeks after inoculation, trials were terminated. Plants were removed from the buckets, their roots washed with tap water, chopped and thoroughly mixed. A sample was collected for nematode extraction using the centrifugal-flotation technique described by Sarah and Boisseau (2008). Two $\mathrm{ml}$ aliquot of the suspension was pipetted in graduated counting dishes and number of nematode determined under a dissecting microscope. The total population density was estimated by converting the value of the aliquot into total volume.

\section{Host suitability of FHIA 21 and PITA 3 to $R$. similis et $P$. coffeae}

The host suitability of the two hybrids was assessed according to two criteria, the reproduction factor as defined by Oostenbrink (1966) and the host resistance classification system developed by Taylor (1967). According to Oostenbrink's formula, nematode reproduction factor $(R)$ is the ratio between the final and initial population $(\mathrm{R}=\mathrm{Pf} / \mathrm{Pi})$. As to Taylor's (1967) classification of host suitability, it compares the reproduction of the assessed genotypes against that of a known susceptible variety of the same species. In the present study, the reproductive capability of FHIA 21 and PITA 3 was compared to that of the reference cultivar HORNE 1. Nematode reproduction rate (T) under the genotypes compared to that under the reference cultivar was calculated as follows: $T$ genotype $\times 100 / \mathrm{T}$ cultivar; $\mathrm{T}=(\mathrm{Pf}-\mathrm{Pi}) / \mathrm{Pi}$, with $\mathrm{T}$ genotype being the reproduction rate of the hybrid, $T_{\text {cultivar }}$ the control reproduction rate, $\mathrm{Pf}$ the final population and $\mathrm{Pi}$ the original inoculum.

Assessment of the incidence of $R$. similis and $P$. coffeae on the vegetative growth of plantain genotypes

Eight (8) weeks after inoculation, the following parameters were recorded: plant height $(\mathrm{cm})$, fresh root weight $(\mathrm{g})$, leaf area $\left(\mathrm{cm}^{2}\right)$ of the second leave. Leaf area was calculated according to Simmond's formula (1962) ( $S F=L \times \mid \times 0.8$ ), where $L$ is the length and I the width of the leaf. The number of leaves produced per plant was also counted and the biomass (\%) determined.

Data statistical analysis: Data consisting of nematodes and agronomic parameters were respectively subjected to $\log (x+1)$ and angular transformations prior to ANOVA analysis with statistica software 9.0 package. Means were compared using Fisher's multiple range test $(P \leq 0,05)$.

\section{RESULTS AND DISCUSSION}

\section{Host suitability of FHIA 21 and PITA 3 to R. similis and $P$. coffeae}

The reproduction factor of $R$. similis is significantly $(\mathrm{P}<0.05)$ lower on hybrid FHIA $21(0.98)$ than PITA 3 (2.48) and the control cultivar HORNE 1 (2.98) (Table 1); the latter two being statistically equivalent. With $P$. coffeae, the reproduction factor was higher than to 2 and was comparable in all three genotypes. According to the classification of Oostenbrink (1966), hybrid FHIA 21 with a reproduction factor below one can be considered a poor host of $R$. similis. As to PITA 3 and HORNE 1, they appeared as good hosts of the population of the banana nematode in Côte d'Ivoire. The results herein challenge the report of the Honduran Fundation for Agricultural Research that characterized the hybrid as susceptible to both $R$. similis and P. coffeae (Anonymous, 1987). However, these results are in accordance with Lassoudière's finding (2009) who has reported resistance of FHIA 21 to $R$. similis in commercial plantations of banana Cavendish in the Republic of Guinea. Resistance of FHIA 21 has also been documented in Cuba after 25 years of FHIA 21 cultivation by Almeres cited by Pocasangré (personal communication, 2015) . On the basis of the reproduction rate of $P$. coffeae on the hybrids, PITA $3(R=2.94)$ and FHIA $21(R=2.99)$ can be considered good hosts of the nematode species ( $P$ $<0.05)$ (Table 1).

On the basis of host resistance classification system developed by Taylor (1967), FHIA 21 with a multiplication rate of $R$. similis of $40 \%$ of that under HORNE 1 was designated "slightly resistant" host to 
the banana nematode. PITA 3 has supported a multiplication rate of $R$. similis representing $80 \%$ of that on HORNE 1; the former was classified as susceptible as the latter (Table 2). As to $P$. coffeae, the rates of multiplication were $73.6 \%$ and $75 \%$ were respectively recorded on PITA 3 and FHIA 21 (Table 3). Like the control cultivar HORNE 1, both hybrids can also be classified susceptible to $P$. coffeae. From the results reported in the present study, and in the light of the recent evolution of the nematofauna associated with banana and plantain cultivation, , the parasitic pressure due to plant-parasitic nematodes in Côte d'Ivoire could be considered exacerbated,. Indeed, for very long the fauna of parasitic nematodes on the crops, was dominated by $R$. similis. Recently however, nematode infection has evolved and is now characterized by the prevalence of $P$. coffeae in plantain and banana orchards (Adiko and N'guessan, 2001; Gnonhouri and Adiko, 2008; Gnonhouri and al., 2009). In the prevailing context, the expected impact from the dissemination of improved plantain varieties with a high production potential could be compromised. Therefore, efficient management measures of $R$. similis and $P$. coffeae must be envisaged. These measures require, among others, the determination of a new damage threshold of the parasites, notably that of the most dominant and aggressive nematode species, $P$. coffeae.

Table 1: Reproduction factor $(R)$ of $R$. similis and $P$. coffeae after eight weeks in monoxenic inoculation under plantain hybrids FHIA 21 and PITA 3 and cultivar HORNE 1

\begin{tabular}{lcc}
\hline Plantain genotypes & \multicolumn{2}{c}{${\text { Reproduction Factor }(\mathrm{R})^{*}}$} \\
\cline { 2 - 3 } & $R$. similis & $P$. coffeae \\
\hline FHIA 21 & $0.98 \pm 0.22 \mathrm{~b}$ & $2.99 \pm 0.03 \mathrm{a}$ \\
PITA 3 & $2.47 \pm 0.54 \mathrm{a}$ & $2.94 \pm 0.50 \mathrm{a}$ \\
HORNE 1 (Control) & $2.97 \pm 0.17 \mathrm{a}$ & $3.99 \pm 0.58 \mathrm{a}$ \\
\hline $\mathrm{F}$ & 33.69 & - \\
$\mathrm{P}$ & 0.005 & - \\
\hline $\mathrm{R}=\mathrm{Pf} / \mathrm{Pi} ; \mathrm{R}:$ reproduction factor, Pf : final population, Pi : initial population
\end{tabular}

For the statistical analyses, reproduction factor data were arc $\sin (\mathrm{x} / 100)$ transformed. Averages in the same column followed by the same letter are not significantly

different $(\mathrm{P} \leq 0.05)$ according to Fisher multiple range test.

Table 2: Reproduction rate (T) of $\boldsymbol{R}$. similis after eight weeks of inoculation under plantain hybrids FHIA 21 and PITA 3 comparatively to the susceptible cultivar HORNE 1

\begin{tabular}{|c|c|c|c|}
\hline Plantain genotypes & $\begin{array}{l}\text { Final population } \\
R \text {. similis/plant }\end{array}$ & $\mathrm{T}(\%)^{*}$ & Degree of resistance \\
\hline FHIA 21 & 1195 & $40.22 \mathrm{c}$ & slightly resistant \\
\hline PITA 3 & 2474 & $83.27 \mathrm{~b}$ & Susceptible \\
\hline HORNE 1 (Control) & 2971 & $100 \mathrm{a}$ & Susceptible \\
\hline $\bar{F}$ & & 24.45 & \\
\hline $\mathrm{P}$ & & 0.0005 & \\
\hline
\end{tabular}

For the statistical analyses, reproduction rate data different $(P \leq 0.05)$ according to Fisher multiple range were arc $\sin (x / 100)$ transformed. Averages in the same column followed by the same letter are not significantly test.

Table 3: Reproduction rate $(\mathrm{T})$ of $P$. coffeae after eight weeks of inoculation under plantain hybrids FHIA 21 and PITA 3 and cultivar HORNE 1

\begin{tabular}{|c|c|c|c|}
\hline Plantain genotypes & $\begin{array}{l}\text { Final population } \\
P \text {. coffeae/plant }\end{array}$ & $\mathrm{T}(\%)^{t}$ & Degree of resistance \\
\hline FHIA 21 & 2996 & $75.01 \mathrm{~b}$ & Susceptible \\
\hline PITA 3 & 2941 & $73.63 b$ & Susceptible \\
\hline HORNE 1 (Control) & 3994 & $100 \mathrm{a}$ & Susceptible \\
\hline $\bar{F}$ & & 66.12 & \\
\hline $\mathrm{P}$ & & $<0.0001$ & \\
\hline
\end{tabular}


For the statistical analyses, reproduction rate data were $\operatorname{arc} \sin (x / 100)$ transformed. Averages in the same column followed by the same letter are not significantly different $(P \leq 0.05)$ according to Fisher multiple range test.

\section{Incidence of $\boldsymbol{R}$. similis and $P$. coffeae on vegetative parameters of plantain hybrids FHIA 21 and PITA 3}

Increasing inoculum levels of nematodes $(0,5,10,15$ and 20 nematodes/g roots) was negatively correlated to the measured agronomic parameters (fresh weight of roots, stem growth, leaf area, biomass and leaf number). With $R$. similis, the incidence of nematode infection was generally recorded under the initial density of 10 nematodes/g fresh roots on FHIA 21 and PITA 3 (Table 4). As for $P$. coffeae, significant incidence of the nematode on all three plantain genotypes was noted from the initial density of 5 nematodes/g roots (Table 5). The result reported here with the initial density of $10 R$. similis per gram of roots confirms the damage threshold set by Guérout (1972). That threshold has served as reference for the implementation of the warning strategy used in the framework of rational nematicide applications in commercial banana orchards in Côte d'Ivoire; strategy based upon the evolution of the nematode infestation in the field, especially that of the most damaging and predominante species Musa spp. in the country, $R$. similis (Sarah, 1989; Adiko and N' guessan , 2001). With $P$. coffeae on the contrary, the damage threshold was noted at 5 nematodes/g roots. All the vegetative parameters measured were significant at that inoculum level on the three plantain genotypes (Table 5). This variation in the incidence of two migratory endoparasitic nematodes may be due, in part, to the differential aggressiveness between the two species. Indeed, the greater damage capacity of $P$. coffeae can be related to the parasite ability to colonize all cellular compartments of the root system (Araya and De Waele, 2004). Furthermore, because of the amphimictic and parthenogenetic reproduction of $P$. coffeae, both male and female nematodes in the population attack the plant in addition to four juvenile stages ( $\mathrm{J} 1$ to $\mathrm{J} 4$ ) that are also infectious (Pinochet and al., 1995). Moreover, the biological life cycle of $P$. coffeae (21 days) compared with that of $R$. similis (28 days) is shorter and the former species, more prolific. As for $R$. similis that has a parthenogenetic reproduction, males are rare, and only female and three juvenile stages (J1 to J3) are infectious (Stoffelen and al., 1999). All these factors could account for the damage threshold of 5 nematodes $/ g$ roots against 10 nematodes $/ g$ roots for $R$. similis reported. In Côte d'ivoire, Gnonhouri and al. (2009) showed that since the evolution of nematofauna associated with Cavendish banana cultivation and characterized by the prevalence of $P$. coffeae, banana orchards are subject to frequent replanting.

\section{Incidence of the cohabitation of $R$. similis and $P$. coffeae on the multiplication rates of nematodes}

In general, $R$. similis accounted for 5 to $28 \%$ of the final population and $P$. coffeae 72 to $95 \%$ in dixenic inoculation, whether the latter was more abundant in the initial population or not (Table 6). With an initial density of $R$. similis equal or higher than that on $P$. coffeae, the final population of the former never exceeded $30 \%$ under the plantain hybrids and cultivar. The final population of nematodes in dixenic inoculation was dominated by P. coffeae (72 to $95 \%)$ in the five initial inoculum densities tested (Table 6). These results account further for the qualitative and quantitative changes that have been recorded with $P$. coffeae in the nematofauna associated with of banana and plantain cultivation in Côte d'ivoire (Gnonhouri and al. 2009; Sarah, 1989 and Adiko and N'guessan, 2001). The great multiplication and damaging capacity of $P$. coffeae requires the adoption of the new threshold of 5 nematodes per gram of roots for the implementation the warning system and the development of other integrated control measures for the management of parasitic nematodes of banana and plantain. 
Table 4: Vegetative growth* of FHIA 21, PITA 3 and HORNE 1 as affected by five inoculum levels of $R$. similis after eight weeks in the glasshouse

\begin{tabular}{|c|c|c|c|c|c|c|c|}
\hline Genotypes & $\begin{array}{l}\text { Inoculum level } \\
\text { (/g roots) }\end{array}$ & $\begin{array}{l}\text { Reproduction } \\
\text { rate }(\mathrm{T})\end{array}$ & $\begin{array}{l}\text { Roots fresh } \\
\text { weight }(\mathrm{g})\end{array}$ & $\begin{array}{l}\text { Pseudostem } \\
\text { growth }(\mathrm{cm})\end{array}$ & $\begin{array}{l}\text { leaf } \\
\text { area }\left(\mathrm{cm}^{2}\right)\end{array}$ & $\begin{array}{l}\text { Top part of the } \\
\text { biomass }(\%)\end{array}$ & $\begin{array}{l}\text { Number } \\
\text { of leaf }\end{array}$ \\
\hline \multirow{6}{*}{ FHIA 21} & 0 & $0.00 \pm 0.00 \mathrm{~b}$ & $15.49 \pm 0.62 \mathrm{a}$ & $3.08 \pm 1.31 \mathrm{a}$ & $157.60 \pm 6.70 \mathrm{a}$ & $87.29 \pm 6.29 \mathrm{a}$ & $6.6 \pm 0.48 \mathrm{a}$ \\
\hline & 5 & $0.74 \pm 0.52 b$ & $15.42 \pm 0.19 \mathrm{a}$ & $2.55 \pm 0.63 \mathrm{a}$ & $142.11 \pm 9.39 \mathrm{~b}$ & $88.01 \pm 6.20 \mathrm{a}$ & $6.2 \pm 0.74 \mathrm{a}$ \\
\hline & 10 & $1.80 \pm 0.36 \mathrm{a}$ & $15.11 \pm 0.71 \mathrm{a}$ & $2.04 \pm 0.70 \mathrm{a}$ & $139.69 \pm 10.14 b$ & $85.65 \pm 5.49 \mathrm{a}$ & $6.0 \pm 0.63 \mathrm{a}$ \\
\hline & 15 & $0.83 \pm 0.11 \mathrm{~b}$ & $12.10 \pm 0.69 \mathrm{~b}$ & $0.57 \pm 0.31 \mathrm{~b}$ & $113.34 \pm 10.88 \mathrm{c}$ & $84.08 \pm 5.34 \mathrm{a}$ & $5.0 \pm 0.63 \mathrm{~b}$ \\
\hline & 20 & $0.23 \pm 0.11 \mathrm{~b}$ & $10.81 \pm 0.68 \mathrm{c}$ & $0.35 \pm 0.31 \mathrm{~b}$ & $109.64 \pm 9.52 \mathrm{c}$ & $75.27 \pm 3.43 \mathrm{~b}$ & $4.4 \pm 0.54 b$ \\
\hline & $\begin{array}{l}\mathrm{F} \\
\mathrm{P}\end{array}$ & $\begin{array}{r}33.70 \\
0.005 \\
\end{array}$ & $\begin{array}{l}55.56 \\
<0.0001 \\
\end{array}$ & $\begin{array}{l}11.25 \\
<0.0001 \\
\end{array}$ & $\begin{array}{r}124.48 \\
<0.0001 \\
\end{array}$ & $\begin{array}{l}7.20 \\
0.009 \\
\end{array}$ & $\begin{array}{r}12.312 \\
<0.0001 \\
\end{array}$ \\
\hline \multirow{6}{*}{ PITA 3} & 0 & $0.00 \pm 0.00 \mathrm{~b}$ & $15.10 \pm 0.97 \mathrm{a}$ & $2.25 \pm 0.98 \mathrm{ab}$ & $136.68 \pm 8.34 \mathrm{a}$ & $87.10 \pm 3.06 \mathrm{a}$ & $7.0 \pm 1.26 \mathrm{a}$ \\
\hline & 5 & $0.98 \pm 0.85 b$ & $15.06 \pm 1.41 \mathrm{a}$ & $3.30 \pm 1.36 \mathrm{a}$ & $131.33 \pm 6.56 \mathrm{a}$ & $88.01 \pm 3.28 \mathrm{a}$ & $6.6 \pm 0.8 \mathrm{a}$ \\
\hline & 10 & $2.47 \pm 0.54 \mathrm{a}$ & $14.58 \pm 1.30 \mathrm{a}$ & $2.81 \pm 1.80 \mathrm{ab}$ & $129.11 \pm 8.59 \mathrm{a}$ & $87.10 \pm 3.31 \mathrm{ab}$ & $6.2 \pm 0.4 \mathrm{a}$ \\
\hline & 15 & $1.20 \pm 0.41 \mathrm{~b}$ & $11.57 \pm 1.31 \mathrm{~b}$ & $1.42 \pm 1.09 \mathrm{~b}$ & $114.81 \pm 4.51 \mathrm{~b}$ & $83.06 \pm 2.00 \mathrm{~b}$ & $5.0 \pm 0.69 \mathrm{~b}$ \\
\hline & 20 & $0.15 \pm 0.10 \mathrm{~b}$ & $10.53 \pm 0.85 b$ & $0.32 \pm 0.33 \mathrm{c}$ & $108.40 \pm 2.89 \mathrm{~b}$ & $75.68 \pm 3.66 \mathrm{~b}$ & $4.4 \pm 0.48 b$ \\
\hline & $\begin{array}{l}\mathrm{F} \\
\mathrm{P}\end{array}$ & $\begin{array}{l}67.45 \\
<0.0001\end{array}$ & $\begin{array}{l}13.09 \\
<0.0001\end{array}$ & $\begin{array}{l}3.74 \\
0.0196\end{array}$ & $\begin{array}{l}13.19 \\
<0.0001\end{array}$ & $\begin{array}{l}13.62 \\
<0.0001\end{array}$ & $\begin{array}{l}7.94 \\
0.0005\end{array}$ \\
\hline \multirow{6}{*}{ HORNE 1} & 0 & $0.00 \pm 0.00 \mathrm{~b}$ & $17.36 \pm 1.09 \mathrm{a}$ & $4.79 \pm 0.77 \mathrm{a}$ & $165.51 \pm 8.46 \mathrm{a}$ & $89.59 \pm 4.51 \mathrm{a}$ & $7.0 \pm 0.89 \mathrm{a}$ \\
\hline & 5 & $1.71 \pm 0.50 \mathrm{~b}$ & $17.13 \pm 0.86 \mathrm{a}$ & $4.33 \pm 1.27 \mathrm{a}$ & $159.36 \pm 10.52 \mathrm{a}$ & $90.73 \pm 3.46 \mathrm{a}$ & $6.6 \pm 0.48 \mathrm{a}$ \\
\hline & 10 & $2.99 \pm 0.19 \mathrm{a}$ & $16.80 \pm 0.67 \mathrm{a}$ & $3.57 \pm 2.07 \mathrm{a}$ & $157.52 \pm 10.16 \mathrm{a}$ & $89.59 \pm 4.51 \mathrm{a}$ & $6.0 \pm 0.63 \mathrm{a}$ \\
\hline & 15 & $1.31 \pm 0.16 \mathrm{~b}$ & $14.11 \pm 0.91 \mathrm{~b}$ & $1.46 \pm 1.22 \mathrm{~b}$ & $129.43 \pm 5.71 b$ & $80.10 \pm 3.44 b$ & $6.0 \pm 0.80 \mathrm{~b}$ \\
\hline & 20 & $0.19 \pm 0.08 b$ & $11.25 \pm 1.50 \mathrm{c}$ & $0.14 \pm 0.13 b$ & $109.85 \pm 7.5 \mathrm{c}$ & $69.16 \pm 1.83 \mathrm{c}$ & $4.6 \pm 0.80 \mathrm{~b}$ \\
\hline & $\begin{array}{l}\mathrm{F} \\
\mathrm{P}\end{array}$ & $\begin{array}{l}55.52 \\
<0.0001\end{array}$ & $\begin{array}{r}25.17 \\
<0.0001\end{array}$ & $\begin{array}{c}9.79 \\
<0.0005\end{array}$ & $\begin{array}{c}30.14 \\
<0.0001\end{array}$ & $\begin{array}{c}25.25 \\
<0,0001\end{array}$ & $\begin{array}{c}9.17 \\
0,0002\end{array}$ \\
\hline
\end{tabular}

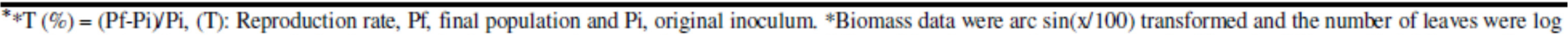

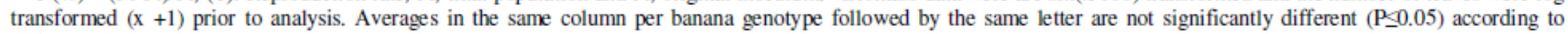
Fisher multiple range test. 
Table 5: Vegetative growth* of FHIA 21, PITA 3 and HORNE 1 as affected by five inoculum levels of $P$. coffeae after eight weeks in the glasshouse

\begin{tabular}{|c|c|c|c|c|c|c|c|}
\hline Genotypes & $\begin{array}{l}\text { Tnoculum level } \\
\text { (/g roots) }\end{array}$ & $\begin{array}{l}\text { Reproduction } \\
\text { rate** }\end{array}$ & $\begin{array}{l}\text { Roots fresh } \\
\text { weight (g) }\end{array}$ & $\begin{array}{l}\text { pseudostem } \\
\text { growth }(\mathrm{cm})\end{array}$ & $\begin{array}{l}\text { leaf } \\
\text { area }\left(\mathrm{cm}^{2}\right)\end{array}$ & $\begin{array}{c}\text { Top part of the } \\
\text { biomass (\%) }\end{array}$ & $\begin{array}{l}\text { Number } \\
\text { of leaf }\end{array}$ \\
\hline \multirow{6}{*}{ FHIA 21} & 0 & $0.00 \pm 0.00 \mathrm{~d}$ & $15.49 \pm 0.62 \mathrm{a}$ & $3.08 \pm 1.31 \mathrm{a}$ & $157.60 \pm 6.70 \mathrm{a}$ & $87.29 \pm 6.29 \mathrm{a}$ & $6.6 \pm 0.48 \mathrm{a}$ \\
\hline & 5 & $1.55 \pm 0.42 b$ & $13.95 \pm 0.53 \mathrm{~b}$ & $0.71 \pm 0.61 \mathrm{~b}$ & $123.99 \pm 3.17 \mathrm{~b}$ & $86.69 \pm 6.00 \mathrm{a}$ & $6.0 \pm 0.63 \mathrm{ab}$ \\
\hline & 10 & $2.99 \pm 0.03 \mathrm{a}$ & $13.35 \pm 0.75 b$ & $0.67 \pm 0.54 \mathrm{~b}$ & $122.39 \pm 2.35 b$ & $86.62 \pm 6.09 \mathrm{a}$ & $5.4 \pm 0.48 \mathrm{~b}$ \\
\hline & 15 & $1.57 \pm 0.49 \mathrm{~b}$ & $10.39 \pm 1.05 \mathrm{c}$ & $0.39 \pm 0.33 b$ & $105.90 \pm 4.82 \mathrm{c}$ & $77.84 \pm 2.15 b$ & $4.8 \pm 0.4 \mathrm{c}$ \\
\hline & 20 & $0.35 \pm 0.33 \mathrm{c}$ & $9.01 \pm 0.43 \mathrm{~d}$ & $0.10 \pm 0.08 \mathrm{~b}$ & $87.17 \pm 4.99 \mathrm{~d}$ & $72.66 \pm 2.12 b$ & $4.4 \pm 0.48 \mathrm{c}$ \\
\hline & $\begin{array}{l}F \\
P\end{array}$ & $\begin{array}{c}36.24 \\
<0.00001\end{array}$ & $\begin{array}{c}55.56 \\
<0.00001\end{array}$ & $\begin{aligned} & 11.25 \\
< & 0.00001\end{aligned}$ & $\begin{array}{l}124.48 \\
<0.00001\end{array}$ & $\begin{array}{l}7.20 \\
0.0009\end{array}$ & $\begin{aligned} & 12.31 \\
< & 0.00001\end{aligned}$ \\
\hline \multirow{6}{*}{ PITA 3} & 0 & $0.00 \pm 0.00 \mathrm{e}$ & $15.10 \pm 0.97 \mathrm{a}$ & $2.25 \pm 0.88 \mathrm{a}$ & $136.68 \pm 8.34 \mathrm{a}$ & $89.95 \pm 3.06 \mathrm{a}$ & $7.0 \pm 1.26 \mathrm{a}$ \\
\hline & 5 & $2.65 \pm 0.69 \mathrm{~b}$ & $13.95 \pm 0.63 b$ & $0.71 \pm 0.51 \mathrm{~b}$ & $123.99 \pm 9.22 \mathrm{~b}$ & $87.29 \pm 3.31 \mathrm{a}$ & $6.0 \pm 0.48 \mathrm{a}$ \\
\hline & 10 & $3.69 \pm 0.88 \mathrm{a}$ & $12.40 \pm 0.35 b$ & $0.38 \pm 0.46 b$ & $122.93 \pm 5.79 \mathrm{~b}$ & $86.75 \pm 3.07 \mathrm{a}$ & $5.4 \pm 0.74 \mathrm{~b}$ \\
\hline & 15 & $1.68 \pm 0.33 \mathrm{c}$ & $10.39 \pm 1.21 \mathrm{c}$ & $0.26 \pm 0.07 \mathrm{~b}$ & $105.90 \pm 4.30 \mathrm{c}$ & $77.84 \pm 2.61 \mathrm{~b}$ & $4.8 \pm 0.4 b$ \\
\hline & 20 & $0.44 \pm 0.17 \mathrm{~d}$ & $9.01 \pm 0.34 \mathrm{~d}$ & $0.10 \pm 0.13 \mathrm{~b}$ & $87.17 \pm 4.20 \mathrm{~d}$ & $72.66 \pm 2.36 \mathrm{c}$ & $4.4 \pm 0.48 b$ \\
\hline & $\begin{array}{l}\mathrm{F} \\
\mathrm{P}\end{array}$ & $\begin{array}{l}85.54 \\
0.005\end{array}$ & $\begin{aligned} & 42.53 \\
< & 0.00001\end{aligned}$ & $\begin{array}{l}9.86 \\
<0.00001\end{array}$ & $\begin{aligned} & 26.53 \\
< & 0.00001\end{aligned}$ & $\begin{aligned} & 25.93 \\
< & 0.00001\end{aligned}$ & $\begin{array}{l}8.62 \\
0.0003\end{array}$ \\
\hline \multirow{5}{*}{ HORNE 1} & 0 & $0.00 \pm 0.00 \mathrm{e}$ & $17.36 \pm 1.09 \mathrm{a}$ & $4.79 \pm 0.77 \mathrm{a}$ & $165.51 \pm 8.46 \mathrm{a}$ & $89.59 \pm 4.51 \mathrm{a}$ & $7.0 \pm 0.89 \mathrm{a}$ \\
\hline & 5 & $2.65 \pm 0.69 \mathrm{~b}$ & $12.94 \pm 0.68 \mathrm{~b}$ & $1.68 \pm 0.82 b$ & $132.18 \pm 6.49 \mathrm{~b}$ & $89.19 \pm 3.94 \mathrm{a}$ & $6.0 \pm 0.63 b$ \\
\hline & 10 & $3.99 \pm 0.58 \mathrm{a}$ & $12.34 \pm 0.80 \mathrm{~b}$ & $1.28 \pm 0.65 \mathrm{~b}$ & $126.58 \pm 2.64 \mathrm{~b}$ & $88.61 \pm 3.46 \mathrm{a}$ & $5.2 \pm 0.74 \mathrm{bc}$ \\
\hline & 15 & $1.68 \pm 0.33 \mathrm{c}$ & $10.66 \pm 0.79 \mathrm{c}$ & $1.02 \pm 0.81 \mathrm{bc}$ & $109.75 \pm 9.45 \mathrm{c}$ & $75.16 \pm 0.93 \mathrm{~b}$ & $4.4 \pm 0.48 \mathrm{~cd}$ \\
\hline & $\begin{array}{r}20 \\
\mathrm{~F} \\
\mathrm{P}\end{array}$ & $\begin{array}{l}0.44 \pm 0.17 \mathrm{~d} \\
85.33 \\
0.0056\end{array}$ & $\begin{array}{l}8.22 \pm 0.12 \mathrm{~d} \\
\quad 76.52 \\
<0.00001\end{array}$ & $\begin{array}{c}0.20 \pm 0.22 \mathrm{c} \\
25.47 \\
<0.00001\end{array}$ & $\begin{array}{c}93.07 \pm 4.78 \mathrm{~d} \\
63.15 \\
<0.00001\end{array}$ & $\begin{array}{c}71.09 \pm 0.76 \mathrm{~b} \\
32.01 \\
<0.00001\end{array}$ & $\begin{array}{c}4.2 \pm 0.4 \mathrm{~d} \\
12.48 \\
<0.00009\end{array}$ \\
\hline
\end{tabular}

${ }^{*} * \mathrm{~T}(\%)=(\mathrm{Pf}-\mathrm{Pi}) / \mathrm{Pi},(\mathrm{T})$ : Reproduction rate, Pf, final population and $\mathrm{Pi}$, original inoculum * Biomass data were $\operatorname{arc} \sin (\mathrm{x} / 100)$ transformed and the number of leaves were log transformed $(\mathrm{x}+1)$ prior to analysis. Averages in the same column per banana genotype followed by the same letter are not significantly different $\left(\mathrm{P} \_0.05\right)$ according to Fisher multiple range test. ${ }^{*} \mathrm{~T}(\%)$ : (Pf-Pi)/Pi, T (\%) Reproduction rate, Pf, final population and $\mathrm{Pi}$, original inoculum 
Table 6: Population of $R$. similis and $P$. coffeae as affected in dixenic inoculation under FHIA 21, PITA 3 and HONE 1 in the greenhouse after eight weeks

\begin{tabular}{|c|c|c|c|c|c|c|c|c|c|}
\hline \multirow{3}{*}{$\begin{array}{l}\text { Inoculum levels } \\
\text { (/g roots) }\end{array}$} & & & & \multicolumn{6}{|c|}{ Final species population/Final population of the 2 species according to the genotype ( $\%$ ) } \\
\hline & \multicolumn{3}{|c|}{ Final populations } & \multicolumn{2}{|c|}{ FHIA 21} & \multicolumn{2}{|c|}{ PITA 3} & \multicolumn{2}{|c|}{ HORNE 1} \\
\hline & Fhia 21 & Pita 3 & Horne 1 & R. similis $(\%)$ & P. coffeae $(\%)$ & R. similis (\%) & P. coffeae $(\%)$ & R. similis (\%) & P. coffeae $(\%)$ \\
\hline 3 R. similis $+3 P$. coffeae & 975 & 991 & 980 & $28.10 \pm 0.43 b$ & $71.90 \pm 0.42 \mathrm{a}$ & $27.88 \pm 0.23 b$ & $72.12 \pm 0.10 \mathrm{a}$ & $26.81 \pm 0.45 b$ & $73.19 \pm 0.13 \mathrm{a}$ \\
\hline $5 R$. similis $+5 P$. coffeae & 2683 & 2710 & 2761 & $20.86 \pm 0.35 b$ & $79.14 \pm 1.25 \mathrm{a}$ & $20.82 \pm 0.15 b$ & $79.18 \pm 1.15 \mathrm{a}$ & $20.10 \pm 0.35 b$ & $79.90 \pm 1.35 \mathrm{a}$ \\
\hline $10 R$. similis $+5 P$. coffeae & 3661 & 3227 & 6631 & $28.51 \pm 0.10 b$ & $71.49 \pm 0.88 \mathrm{a}$ & $27.18 \pm 0.11 b$ & $72.82 \pm 0.28 \mathrm{a}$ & $29.07 \pm 0.14 b$ & $70.93 \pm 1.08 \mathrm{a}$ \\
\hline 5 R. similis $+10 P$. coffeae & 2865 & 2889 & 2895 & $5.71 \pm 0.11 b$ & $94.29 \pm 0.52 \mathrm{a}$ & $5.94 \pm 0.15 b$ & $94.06 \pm 0.02 \mathrm{a}$ & $6.14 \pm 0.12 b$ & $93.86 \pm 0.52 \mathrm{a}$ \\
\hline 10 R. similis $+10 P$. coffeae & 4589 & 4632 & 4749 & $16.06 \pm 0.23 \mathrm{~b}$ & $83.94 \pm 0.76 \mathrm{a}$ & $16.08 \pm 0.03 \mathrm{~b}$ & $83.92 \pm 0.36 \mathrm{a}$ & $14.28 \pm 0.43 b$ & $85.72 \pm 1.21 \mathrm{a}$ \\
\hline
\end{tabular}

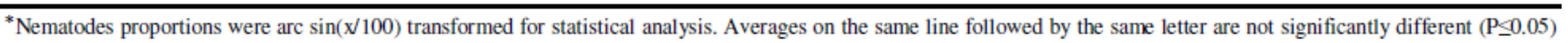
according to Fisher multiple range test. 


\section{CONCLUSION}

The study of the host status of tetraploid plantain FHIA 21 and PITA 3 demonstrated that the former was resistant to $R$. similis. Relatively to $P$. coffeae instead, FHIA 21 appeared as a good host. Like the reference cultivar HORNE 1, PITA 3 appeared susceptible to both nematode species. Assessment of the incidence of increasing initial density levels of $R$. similis and $P$. coffeae lead to the establishment of a damage threshold of $5 P$. coffeae per gram of roots, and the confirmation of Guerout's threshold for $R$. similis, 10 nematodes per gram of roots. $P$. coffeae appeared also more aggressive than the banana nematode as in dixenic inoculation, its population prevailed over that $R$. similis whatever the initial density level. Due to the recomposing of nematode fauna under banana and plantain in Côte d'Ivoire, the new damage threshold of 5 nematodes/gr of root should be considered for the management of plant-parasitic nematodes associated with these crops.

\section{ACKNOWLEDGEMENTS}

The study here reported was supported financially by the Fonds Interprofessionnel pour la Recherche et le Conseil Agricoles of Côte d'Ivoire (FIRCA), on behalf of the World Bank and the Government of Côte d'Ivoire, in the framework of the West Agricultural Productivity Program (WAAPP) of the ECOWAS.

\section{REFERENCES}

Adiko A (1989). Nematodes seasonal fluctuation and yield losses in two plantains cultivars, Musa (AAB), in Côte d'Ivoire. Agronomie Africaine 1 (2) : 25-34.

Adiko A et N'guessan AB (2001). Evolution de la nématofaune du bananier plantain (Musa $A A B$ ), in Côte d'Ivoire. Infomusa, 10: 2-2.

Anonymous (1987). A high yielding plantain for national markets resistant to black sigatoka fungus. Banana and plantain program. Honduran Fundation for Agricultural Research, $4 \mathrm{P}$.

Anonymous (2016). Etude de la filière Banane Plantain en Côte d'Ivoire. Projet " Promotion et commercialisation de la Banane Plantain et du Manioc en Côte d'Ivoire "financé par le Comité Français pour la Solidarité Internationale (CFSI), 62 $P$.

Araya $M$ et De waele D (2004). Spatial distribution of nematodes in three banana (Musa $A A A$ ) root parts considering two root thickness in three farm management systems. Acta Oecologica $26: 137-148$.
Baker B., Zambriski P., Staskaviez B and Dinesh-kumar SP (1997). Signaling in plant-microbe interaction. Science, 276 (5313) : 726-733.

Boisseau M et Sarah JL. (2008). In vitro rearing of Pratylenchidae nematodes on carrot discs. Fruits, 63 (5) : 307-310.

Bridge J., Sikora RA et Luc M (2005). Plant parasitic nematodes in subtropical and tropical agriculture, $2^{\text {nd }}$ Edition. CABI Bioscience Egham, UK, 871p.

De Waele D (1996). Plant resistance to nematodes in other crops: relevant research that may be applicable to Musa. Pp. 108-115 in New Frontiers in Resistance Breeding for Nematodes, Fusarium and Sigatoka (Frison E.A., Horry J-P. et De Waele D., eds). INIBAP, Montpellier, France.

Gnonhouri P et Adiko A (2008). Distribution géographique de Radopholus similis et Pratylenchus coffeae. Risque potentiel sur la pérennisation des plantations de bananiers dessert en Côte d'ivoire. Agronomie Africaine, 20 (2) : 213- 220.

Gnonhouri P., Adiko A., Kobenan K et Aké S (2009). Longévité des bananeraies industrielles en relation avec le parasitisme des nématodes Radopholus similis et Pratylenchus coffeae en Côte d'ivoire. Journal of applied biosciences 19:1100-1111.

Gowen S et Queneherve P (1990). Nematode parasites of bananas, plantains and abaca. In

Plant Parasitic Nematodes In Subtropical and Tropical Agriculture. Luc M. Sikora R. A. et Bridge J., eds : 431-460.

Guérout R (1972). Relation entre les populations de Radopholus similis Cobb et la croissance du bananier. Fruits, 27, 331-337.

Jones DR (2000). Fungal diseases of the foliage. Pp. 37141. In Diseases of banana, Abaca and Ensete. (D.R. Jones ed.) CAB International, Wallingford, Oxon, UK, $544 \mathrm{p}$.

Lassoudière A (2009). Le bananier et sa culture. Connaissance de la plante. Interaction avec le milieu écologique. Ed Quae, Versailles, France. 383 p.

Oostenbrink M (1966). Major characteristics of the relation between nematodes and plants. Meded. Landbouw. Wageningen $n^{\circ} .66-4$.

Pinochet J (1996). Review of past research on Musa germplasm and nematode interactions. Pp. 32-44. In New Frontiers in Resistance Breeding for Nematodes, Screening of Musa germplasm for resistance and tolerance to nematodes Fusarium and Sigatoka (Frison E.A., Horry J-P. and De Waele D., eds). INIBAP, Montpellier, France.

Pinochet J., Fernandez C et Sarah JL (1995). Influence of temperature on in vitro reproduction of Pratylenchus coffeae, $P$. goodeyi and Radopholus similis. Fundam. Appl. Nematol., 1995, 18 (4), 391 392.

Sarah, JL (2000). In: Diseases of banana, abaca and ensete. 295-303. C.A.B International, Wallingford. 
Sarah JL (1989). Bananas nematodes and their control in Africa. Nematropica, 19 (2): 199-216.

Sarah JL., Pinochet J et Stanton J (1996). Radopholus similis Cobb, nématodes parasites des bananiers. Parasites et ravageurs des Musa. Fiche technique $\mathrm{n}^{\circ} 1$, INIBAP, Montpellier, France. $2 \mathrm{Pp}$.

Seinhorst JW (1950). De Betekenis van de Toestand van de Grond voor het stengelaaltje (Ditylenchus dipsaci Filipjev), $40 \mathrm{p}$.

Simmonds NW (1962). The evolution of bananas. Longman Eds. London, $300 \mathrm{p}$.

Stoffelen R., Jimenez MI., Dierckxsens C., Tam VTT., Swennen R and De Waele D (1999). Effect of time and inoculum density on the reproductive fitness of Pratylenchus coffeae and Radopholus similis populations on carrot disks. Nematology 1: (3) 243250.

Taylor AL (1967). Introduction to research on plant nematology. FAO, UN, Pub. No. 1PL:CP/5. Rome, Italy. $133 \mathrm{pp}$.

Thiemele DEF., Issali AE., Traore S., Kouassi KM., Aby N., Gnonhouri GP., Kobenan K., Yao NT., Adiko A et Zakra NA (2015). Macropropagation of plantain (Musa spp.) cultivars PITA 3, FHIA 21, ORISHELE and CORNE 1: effect of benzylaminopurine (BAP) concentration. J. Plant Develop, 22 (2015) : 31-39

Vuylsteke D., Ortiz R and Swennen R (1993). Genetic improvement of plantains and banana at IITA. Info musa, 2:(1)10-10.

Cite this Article: Vawa OST, Adiko A, Gnonhouri GP, Otchoumou A (2016). Host Status of Plantain Hybrids FHIA 21 and PITA 3 for Populations of Radopholus similis and Pratylenchus coffeae in Côte D'ivoire. Greener Journal of Agricultural Sciences, 6(9): 262-271, http://doi.org/10.15580/GJAS.2016.9.101416162. 